\title{
An overview of occupational noise-induced hearing loss among workers: epidemiology, pathogenesis, and preventive measures
}

\author{
Kou-Huang Chen', Shih-Bin Su² and Kow-Tong Chen ${ }^{3,4^{*}}$
}

\begin{abstract}
Occupational noise-induced hearing loss $(\mathrm{ONIHL})$ is the most prevalent occupational disease in the world. The goal of this study was to review the epidemiology, pathogenesis, and preventive measures of ONIHL among workers and provide evidence for the implementation of control measures. Literature studies were identified from the MEDL INE, PubMed, Embase, Web of Science, and Google Scholar using the search terms "noise-induced hearing loss" "prevalence", "pathogenesis", and "preventive measures". The articles reviewed in this report were limited from 2000 to 2020. Articles that were not published in the English language, manuscripts without an abstract, and opinion articles were excluded. After a preliminary screening, all of the articles were reviewed and synthesized to provide an overview of the current status of ONIHL among workers. The mechanism of ONIHL among workers is a complex interaction between environmental and host factors (both genetic and acquired factors). The outcomes of noise exposure are different among individual subjects. Clinical trials are currently underway to evaluate the treatment effect of antioxidants on ONIHL. Noise exposure may contribute to temporary or permanent threshold shifts; however, even temporary threshold shifts may predispose an individual to eventual permanent hearing loss. Noise prevention programs are an important preventive measure in reducing the morbidity of ONIHL among workers.
\end{abstract}

Keywords: Noise-induced hearing loss, Occupational diseases, Prevalence, Pathogenesis, Preventive measures

\section{Introduction}

Hearing loss due to noise exposure in the workplace is a significant health problem worldwide $[1,2]$. Occupational noise-induced hearing loss (ONIHL) is a common occupational disease. Since the eighteenth century, reports have noted that copper miners experienced hearing loss due to the noise exposure from hammering on metal $[3,4]$. It is estimated that 1.3 billion people suffer from hearing loss due to noise exposure [3]. Worldwide, occupational noise exposure is responsible for $16 \%$ of

\footnotetext{
*Correspondence: ktchen@mail.ncku.edu.tw

${ }^{3}$ Department of Occupational Medicine, Tainan Municipal Hospital (managed by Show Chwan Medical Care Corporation), No. 670, Chongde Road, East District, Tainan 701, Taiwan

${ }^{4}$ Department of Public Health, College of Medicine, National Cheng Kung University, Tainan 701, Taiwan

Full list of author information is available at the end of the article
}

cases of disabling hearing loss in adults $[1,3,5]$. This indicates that ONIHL does not directly cause premature mortality but does result in substantial disability.

The impacts of occupational noise exposure cause a tremendous financial and disease burden on both individual and society. In the USA, it is estimated that the annual compensation for ONIHL is approximately $\$ 242.4$ million [3, 6]. This economic burden on society is extremely high and continually increasing. Previous studies have indicated that workers employed in the construction, manufacturing, mining, agriculture, utility, and transportation, industries, military personnel, and musicians have the highest risk for ONIHL [7-9].

ONIHL can limit an individual's ability to communicate with others and can lead to increased social stress, sadness, diminish confidence, poor self-identity, and bad 
interpersonal relationships [6, 9]. Commonly, hearing loss interferes with communication and can hinder personal attention and cognition $[6,9]$. Older people with mild hearing loss have a twofold increased risk of dementia, whereas those with severe hearing loss have a fivefold increased risk of dementia [10]. ONIHL is a complex and preventable disease $[11,12]$. Understanding the mechanism of ONIHL and distribution of those affected by ONIHL is important to develop proper preventive measures. Therefore, the aim of this study was to explore the prevalence, pathogenesis, and preventive measures of ONIHL.

\section{Methods}

In preparing this review, we searched several online databases, including MEDLINE (National Library of Medicine, Bethesda, Maryland, USA), PubMed, Embase, Web of Science, and Google Scholar for relevant published papers using a combination of the following keywords "noise-induced hearing loss", "prevalence", "pathogenesis", and "preventive measures". The references listed in the retrieved studies were also searched in an attempt to find additional relevant studies. The steps of the review process followed the preferred reporting items for systematic reviews and meta-analysis (PRISMA) guidelines. The inclusion criteria of papers for reviewing were exposure to occupational noise alone or in combination with other factors, hearing loss and other health outcomes, and the statistical association between occupational noise and hearing loss/other health outcomes. We screened all reference lists of relevant studies in order to identify any missing publications. The literature review was completed in March 2020.

\section{Results and discussion}

A total of 1230 documents were retrieved from the abovementioned sources. All titles and abstracts from the literature search were assessed by two investigators against the inclusion criteria for possible relevance independently. We solved any discrepancies through consensus. References that we judged to be potentially relevant were read in full text and evaluated. Relevant original studies were quality-assessed by one of the investigators using a checklist developed by Hoogendoorn et al. [13] for the evaluation of observational studies. We defined high quality as a score of more than $50 \%$ on the internal validity scale of the checklist. The articles reviewed in this report were limited from 2000 to 2020. Articles that were not published in the English language, manuscripts without an abstract, and opinion articles were excluded. Finally, a total of 105 documents were considered for review (Fig. 1).

After the articles were selected, we extracted potential information related to epidemiology, pathogenesis, and preventive measures and classified the information accordingly.

\section{Defining ONIHL and related information}

ONIHL is defined as a partial or complete hearing loss in one or both ears as the result of one's employment; it is a function of continuous or intermittent noise exposure and usually develops slowly over several years [14]. ONIHL is different from the acoustic trauma, which is characterized by a sudden change in hearing as a result of a single exposure to a sudden burst of sound, such as explosive blasts, gunfire, and attendance at loud concerts $[14,15]$. Although there is increasing evidence that asymmetrical hearing loss occurs among individuals with ONIHL [16], typically, ONIHL is a sensory neural phenomenon involving injury to the inner ear. It is bilateral and symmetrical, usually affecting the higher frequencies at $4 \mathrm{kHz}$, with spread to neighboring frequencies of 3 and $6 \mathrm{kHz}$, and some hearing recovery at $8 \mathrm{kHz}[14,17]$. With further noise exposure, the hearing loss can involve the lower frequencies at $0.5,1$, or 2 $\mathrm{kHz}$ [4]. ONIHL is proposed to be on average no higher than $75 \mathrm{~dB}$ in the high frequencies and no higher than $40 \mathrm{~dB}$ in the lower frequencies [18]. Four grades of hearing impairment are classified by the WHO: slight (audiometric ISO value 20-40 dB), moderate (41-60 dB), severe $(61-80 \mathrm{~dB})$, and profound $(81 \mathrm{~dB}$ or greater) $[14,19]$. The audiometric ISO values are averages of values at $0.5,1,2$, and $4 \mathrm{kHz}$. Self-reported hearing problems and physical examinations are sometimes used for the detection of ONIHL in the workplace [20].

The Occupational Safety and Health Administration (OSHA) and the National Institute for Occupational Safety and Health (NIOSH) provided the standard exposure levels of noise [21-23]. For OSHA [21], the permissible exposure limit (PEL) in the occupational noise exposure standard (29 CFR 1910.95) is $90 \mathrm{dBA}$, for an 8$\mathrm{h}$ time-weighted average (TWA) with a 5-dB exchange rate (increase or decrease in $\mathrm{dB}$ corresponding to doubling or halving the noise dose). An action level of 85 dBA, for an 8-h TWA (50\% of PEL) was added in the 1983 Hearing Conservation Amendment (HCA), in which a hearing conservation program must be made available to workers whose exposures equal or exceed the action level. In addition, an 80- $\mathrm{dB}$ threshold level in the computation of noise dose was proposed in the OSHA-HCA criteria. By including sound energy doses from 80-90 dBA, the noise dose measured under the OSHA-HCA criteria is typically higher than the corresponding compliance measurement.

For NIOSH, an 8-h time-weighted average exposure limit of $85 \mathrm{dBA}$ and a $5-\mathrm{dB}$ exchange rate were recommended in the 1972 Criteria for a Recommended Standard: Occupational Exposure to Noise [22]. These criteria were further revised in 1998. The recommended exposure limit (REL) remains at $85 \mathrm{dBA}$, but the $5-\mathrm{dB}$ exchange rate has been replaced with a $3-\mathrm{dB}$ exchange 


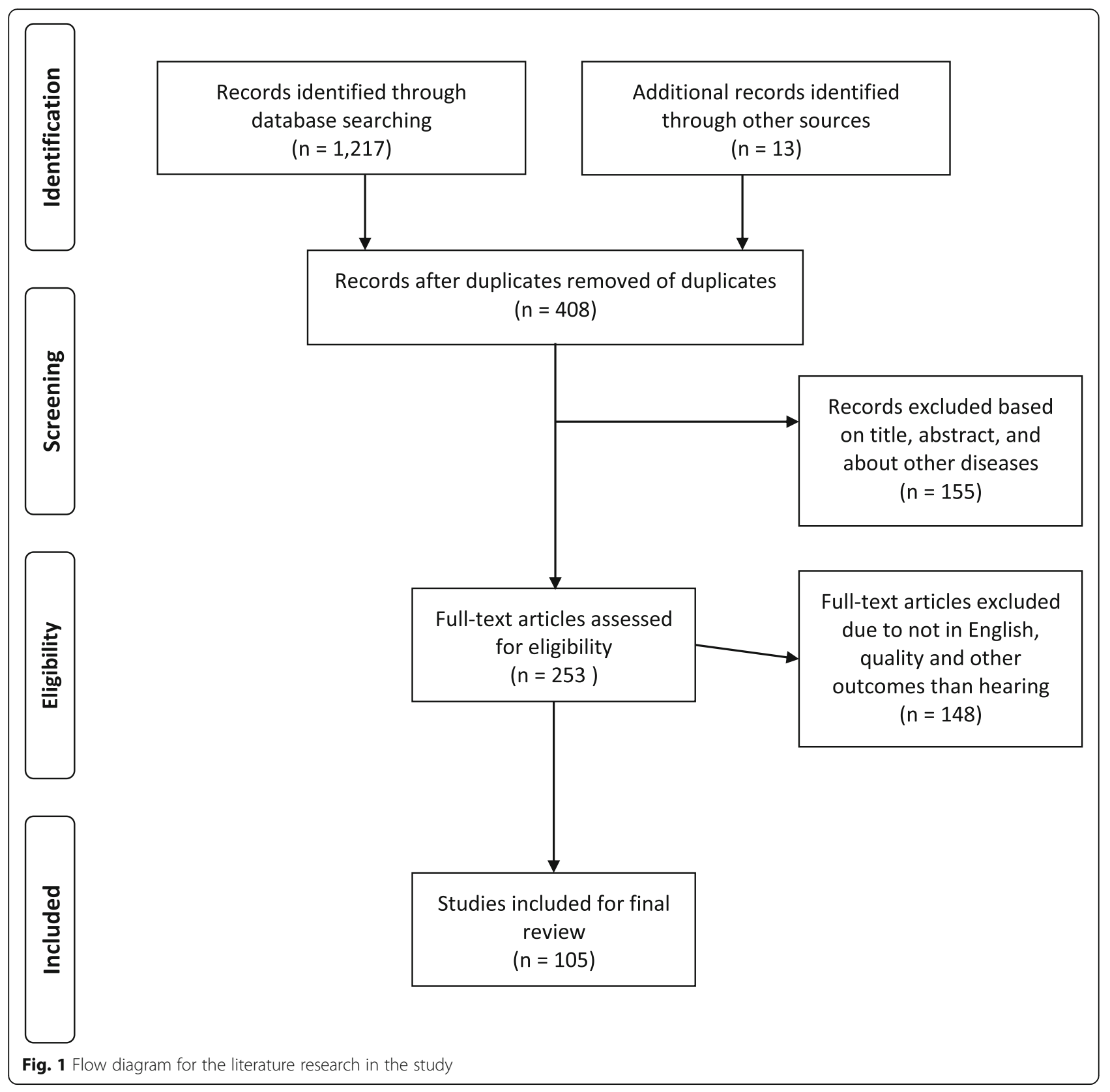

rate. Therefore, under this requirement of an exchange rate of $3-\mathrm{dB}$, a $4-\mathrm{h}$ of exposure at $88 \mathrm{dBA}$ is as equally hazardous as $8 \mathrm{~h}$ at $85 \mathrm{dBA}$. Furthermore, all workers exposed to noise levels above the REL are recommended to be enrolled in a hearing loss prevention program (HLPP) [22, 23]. The main difference between the NIOSH criteria and the OSHA-HCA criteria is that the former used $85 \mathrm{dBA}$ with a $3-\mathrm{dB}$ exchange rate for noise exposure measurements, whereas the latter uses $90 \mathrm{dBA}$ with a 5-dB exchange rate [24]. A previous study showed that when the NIOSH criteria were adopted as an OSHA standard, there was a 2.7 -fold increase in the number of workers enrolled in a hearing prevention program [24].
The International Organization for Standardization provided criteria for safe noise levels in ISO-1999 [25]. The ISO-1999 standard of noise exposure is based on data collected during the 1950s and 1960s [26]. The studies used to prepare the ISO-1999 standard mainly considered steady-state noise exposure [27]. The safe doses of noise exposure required in this standard assume that hearing loss is a function of total exposure ignoring the effects of the temporal characteristics of noise and complex noise environments [28]. Accordingly, this standard provides lower estimates of the risk of noiseinduced hearing loss (NIHL). To solve this problem, a new noise metric with a temporal correction term was 
designed. A previous study showed that the kurtosis correction term generally improves the correlations of metrics with NIHL [29]. Furthermore, the current NIOSH guidelines suggest that a $140-\mathrm{dB}$ sound pressure level (SPL) limit should be used for impulsive noise, whereas an $85 \mathrm{dBA}$ permissible exposure level (PEL) with a 3-dB exchange rule should be used for complex noise [21]. Recent studies have shown that SPL combined with a kurtosis correction term may serve as a good noise metric for the assessment of ONIHL risk $[29,30]$.

\section{Epidemiology}

The morbidity of ONIHL has been estimated for different countries. The criteria for ONIHL among workers vary from country to country [6-9]. The burden associated with occupational noise varies from 11.2\% (South Africa) to 58\% (USA) (Table 1) [31-65]. Overall, the prevalence of ONIHL is generally higher in the less developed regions of the world [3].

Previous studies have shown that males experience more effects after exposure to occupational noise than females $[1,66]$. This may be due to males usually having greater exposure to noise at work than females due to differences in occupational categories, economic sectors of employment, and lifetime work history. Another possible reason is the hormone-driven physiological differences between sexes. Several animal and human studies have demonstrated that women may be protected against hearing loss because of estrogen and its signaling pathways [66].

The age groups from 30-44 and 45-59 years are at higher risk when exposed to occupational noise, corresponding to the ages of peak labor force participation [67]. A previous study showed that the affected fraction decreased by age group after 30-44 years old [1],

Table 1 A summary of the prevalence of noise-induced hearing loss among workers in the world by year reported by occupation by country, 2009-2019

\begin{tabular}{|c|c|c|c|c|}
\hline $\begin{array}{l}\text { Year of } \\
\text { reported }\end{array}$ & $\begin{array}{l}\text { Countries/ } \\
\text { regions }\end{array}$ & Population/exposure/sex/age & $\begin{array}{l}\text { Prevalence (hearing } \\
\text { threshold) }\end{array}$ & Reference \\
\hline \multirow[t]{2}{*}{2009} & French & $\begin{array}{l}\text { Policemen }(N=887) \\
\text { Mean age: } 37.6 \text { years }\end{array}$ & $28 \%(\geqq 30 \mathrm{~dB})$ & [31] \\
\hline & & $\begin{array}{l}\text { Civil servants }(N=805) \\
\text { Mean age: } 41.8 \text { years }\end{array}$ & $16 \%(\geqq 30 \mathrm{~dB})$ & \\
\hline 2010 & Norway & $\begin{array}{l}\text { General population }(N=49,948) \\
\text { Mean age: } 48.0 \text { years }(20-101)\end{array}$ & $10.3 \%(\geqq 35 \mathrm{~dB})$ & [32] \\
\hline 2011 & Dutch & $\begin{array}{l}\text { Construction } / \text { male workers }(N=24,670) \\
\text { Mean age: } 44.3 \text { years }\end{array}$ & $22.1 \%(\geqq 40 \mathrm{~dB})$ & [33] \\
\hline 2012 & Ghana & $\begin{array}{l}\text { Stone crushing workers ( } N=140 \text {; male: } 137 \text {, female: } 3 \text { ) } \\
\text { Mean age: } 42.6 \text { years }\end{array}$ & $21.5 \%(\geqq 34 \mathrm{~dB})$ & {$[34]$} \\
\hline \multirow[t]{2}{*}{2012} & South Africa & Gold miners (underground noise exposure; $N=33,749$ ) & $11.2 \%(\geqq 40 \mathrm{~dB})$ & {$[35]$} \\
\hline & & Gold miners (surface noise exposure; $N=7456$ ) & $14.1 \%(\geqq 40 \mathrm{~dB})$ & \\
\hline 2013 & Zimbabwe & $\begin{array}{l}\text { Mining workers }(N=169 ; \text { male }=158 \text {, female }=11) \\
\text { Mean age: } 34.8 \text { years }\end{array}$ & $37 \%(\geqq 40 \mathrm{~dB})$ & [36] \\
\hline 2014 & Ghana & Market mill workers $(N=101)$ & $24.8 \%(\geqq 25 \mathrm{~dB})$ & {$[37]$} \\
\hline \multirow[t]{2}{*}{2015} & Nepal & $\begin{array}{l}\text { Carpenters/male }(N=88) \\
\text { Median age: } 23 \text { years }(20-31)\end{array}$ & $31 \%(\geqq 50 \mathrm{~dB})$ & [38] \\
\hline & & $\begin{array}{l}\text { Sawyers/male }(N=36) \\
\text { Median age: } 30 \text { years }(20-45)\end{array}$ & $44 \%(\geqq 50 \mathrm{~dB})$ & \\
\hline \multirow[t]{2}{*}{2016} & USA & $\begin{array}{l}\text { Mining workers ( } N=7398 \text {; male: } 7895, \text { female: } 3 \text { ) } \\
\text { Median age: } 38.7 \text { years (18-75) }\end{array}$ & $24 \%(\geqq 40 \mathrm{~dB})$ & [39] \\
\hline & & $\begin{array}{l}\text { Oil and gas extraction ( } N=1072 \text {; male: } 977 \text {, female: } 95) \\
\text { Median age: } 36.0 \text { years }(16-79)\end{array}$ & $14 \%(\geqq 40 \mathrm{~dB})$ & \\
\hline 2018 & USA & $\begin{array}{l}\text { AFFH sector ( } N=17,290 ; \text { male: } 12,482 \text {, female: } 4808) \\
\text { Media age: } 34.9 \text { years }(18-75)\end{array}$ & $15.0 \%(\geqq 40 \mathrm{~dB})$ & [40] \\
\hline 2018 & USA & $\begin{array}{l}\text { Construction workers } / \text { male }(97 \%) / \text { Caucasian }(89 \%)(\text { total } N=19 \text {, } \\
\text { 127) } \\
\text { Mean age }=59.2 \text { years }\end{array}$ & $58 \%(\geqq 40 \mathrm{~dB})$ & [41] \\
\hline 2019 & South Thailand & $\begin{array}{l}\text { Sawmill workers ( } N=699 ; \text { male: } 335 \text {, female: } 364) \\
\text { Mean age: } 33.5 \text { years }( \pm 10.2)\end{array}$ & $22.8 \%(\geqq 25 \mathrm{~dB})$ & {$[42]$} \\
\hline 2019 & China & Automotive manufacturing ( $N=6667$; male: 6427, female: 240$)$ & $28.8 \%(\geqq 30 \mathrm{~dB})$ & [43] \\
\hline
\end{tabular}


indicating the heavy impact of occupational noise on the burden of hearing loss at younger ages [1-3]. If people suffering from hearing loss at a younger age have a longer duration of disability, then more years of disability contribute to the disability-adjusted life year (DALY) calculation.

It has been reported that ONIHL among workers has been significantly associated with an increased risk of work-related injuries [68]. The suggested reasons for this finding are that higher noise levels obstruct the ability to hear warning signals, monitor equipment, react to environmental sounds, and coordinate with other workers. The burden of hearing loss among noise-exposed workers varies by industry and occupation. Overall, the industries at the highest risk for hearing loss are the mining, textile, buildings construction, and wood product manufacturing sectors [31-65].

In addition to auditory outcomes, ONIHL has also been associated with a number of nonauditory sequelae. Bad mood, poor cognition, sleep disorders, and cardiovascular diseases are the frequent complications of ONIHL [6]. Previous studies have shown that higher levels of noise exposure are associated with higher morbidity and mortality of cardiovascular disease [69-74]. It is estimated that people with hearing loss have $10-20 \%$ excess mortality [75]. It has been suggested that noise exposure induces reaction of the autonomic nervous system and endocrine system, leading to increased secretion of the stress hormone, which in turn may lead to an increased risk of hypertension, coronary heart disease, and stroke $[76,77]$.

\section{Pathogenesis}

The burden of hearing loss related to the specified noise exposure is variable. Similar to the processes of other diseases, the pathogenesis of ONIHL shows a complex interaction between genetic and environmental factors. It has been reported that up to $50 \%$ of individual variations in people with ONIHL may be associated with hereditary factors [36]. In addition, individual demographic factors such as age, preexisting sensorineural hearing loss, chronic diseases (e.g., hypertension and diabetes mellitus), history of smoking, and use of ototoxic medications may influence the degree of damage to the inner ear caused by noise injury [5].

The human auditory system is composed of the outer ear, middle ear, and inner ear. The outer ear gathers sound energy and transmits it to the middle ear through the ear canal and the tympanic membrane and then transmits the vibrations to the inner ear through the three tiny bones (malleus, incus, stapes) in the middle ear [4]. These vibrations are conveyed to the cochlea, where they generate pressure to vibrate the basilar membrane, where hair cells convert it to action potentials
[78]. Mechanical coupling causes sound energy to be efficiently transmitted from the air to the cochlea. A previous study indicated that hair cell electrical responses transduce sound via submicrometer deflections of hair bundles, which are arrays of interconnected stereocilia containing mechanotransducer (MT) channels [78]. Activation of MT channels is initiated by tension in extracellular tip links bridging adjacent stereocilia, and they can respond within microseconds to nanometer displacements of the bundle, facilitated by several steps of $\mathrm{Ca}^{2+}$-dependent adaptation. The vibrations are converted by the inner hair cells into electrical impulses, and the impulses are delivered to the brain through the auditory nerve $[4,30]$. The inner ear has two parts, the vestibular system and the cochlea. The organ of Corti, a specialized sensory epithelium resting on the basilar membrane in the cochlea, is composed of thousands of delicate hair cells (auditory sensory cells) and supporting cells [79]. The organ of Corti contains two classes of hair cells, inner hair cells (IHCs) contacting the majority of the afferent nerve fiber and outer hair cells (OHCs) which play a role in amplifying the mechanical stimulus and have the majority of efferent innervations [80]. The function of IHCs is relaying acoustic information via multiple ribbon synapses that transmit rapidly without exhaust. OHCs are important for amplifying soundinduced vibrations. The amplification mechanism primarily involves contraction of outer hair cells, which are driven by changes in membrane potential and mediated by the protein prestin [80]. The cochlea also plays the role of a spectrum analyzer in which different sound frequencies are separated along the cochlea, with each hair cell being tuned to a narrow frequency range; amplification sharpens the frequency resolution and augments sensitivity 100-fold around the cell's characteristic frequency. Genetic mutations and environmental factors such as acoustic overstimulation cause hearing loss through irreversible damage to the hair cell or degeneration of the inner cell system [78]. The stereociliary (hair) bundle, projecting from the top face of hair cells, is the organelle through which all mechanical stimuli are focused for detection by the transduction machinery. The hair cells in the organ of Corti can be destroyed by various factors, e.g., aging, loud noise, ototoxic chemicals, and ototoxic medications. Among these factors, exposure to loud noise is the most common cause of irreversible injury to hair cells, causing permanent sensorineural hearing loss [81].

ONIHL is an insidious illness and may progress until it advances to hearing disability [6]. Exposure to loud noise can result in a temporary threshold shift (TTS) and/or a permanent threshold shift (PTS) [82]. Continued exposure to excessive noise may lead to impaired transmission of both low- and high-frequency sounds to 
the brain $[80,82]$. Furthermore, the cochlear blood flow may be poor; hair cells bear stereocilia on the apical surface and these can become a fused, splayed, or missing stereociliary bundle arrangement after significant noise exposure, hair cells and supporting structures disrupt hearing function; and ultimately, even nerve fibers that innervate hair cells disappear [83-86]. Changes in the stria vascularis are likely to decrease endocochlear function, thus decreasing the cochlear amplifying function for auditory signals and increasing the auditory threshold [87]. Along with the degeneration of cochlear nerve fibers, there is simultaneous degeneration within the central nervous system [30]. Because hair cells in mammalian species do not regenerate, once hair cells are destroyed, ONIHL is present permanently, regardless of the pathway of hair cell destructions [85].

Pure tone audiometric testing is used to detect and quantify the degree of ONIHL [88]. This provides a subjective measurement of hearing loss in individuals exposed to occupational noise and requires a voluntary response on the part of the person being tested [25]. The main characteristics of ONIHL are that most noise exposures are symmetric and display typical signs of notching at high frequencies of 3000, 4000, or $6000 \mathrm{~Hz}$ with recovery at $8000 \mathrm{~Hz}$ in audiogram testing $[6,89]$. This notch presents at one of these frequencies and does not actually influence neighboring frequencies but once a notch occurs, additional frequencies may demonstrate notches, and the prominence of this notch may be affected by age-related hearing loss [89]. Therefore, ONIHL needs to be differentiated from age-related hearing loss in older persons.

Typically, ONIHL is bilateral and symmetric. However, there may be some atypically asymmetric presentation in hearing loss, particularly if there is a different degree of exposure to sound between the two ears. When a discrepancy is present, ONIHL is commonly more severe in the left ear, although the reasons for this phenomenon are still unclear [4]. It is estimated that approximately $90 \%$ of the world population is right-handed [88]. Some arguments have been raised that a person with right-handedness may be more likely to leave the left ear turned toward a noise-source from machine engine [41]. Similarly, for those who shoot firearms or play musical instruments, more severe hearing impairment is noted in the ear closest to the gun barrel or to one's location within the band or orchestra, and the opposite ear receives relatively lower amplitude of sound due to the acoustic shadow effect $[26,41]$.

Recently, another theory of oxidative stress has been proposed to play a possible role in the pathogenesis of ONIHL $[84,90]$. Reactive oxygen species (ROS) are a normal byproduct of cellular respiration, and a certain level of intracellular ROS is necessary for various cellular processes. However, excessive loads of ROS cause oxidative damage to DNA, lipids, and proteins and result in cell death [91, 92]. Previous studies have shown that noise exposure increases the levels of ROS in the cochlea, following by activation of signaling pathways leading to cell death $[93,94]$. Although ROS play a role in the cascade of ONIHL, the mechanism by which noise generates these free radicals is still unknown [94]. Based on these hypotheses, some antioxidant compounds, e.g., Nacetyl-L-cysteine and D-methionine, are undergoing clinical trials for their use as otoprotective agents [95101]. However, these agents are still in the animal study stage. More research is needed in the future.

In addition to continuously high levels of noise, short bursts of loud sound may also result in ONIHL [24]. Short bursts of loud sounds lead to cochlear hair cell injury and injury to the inner ear surrounding supporting cells, resulting in the degeneration of auditory nerve fibers [83]. A previous study indicated that noise exposure of at least $130 \mathrm{~dB}$ sound pressure level (SPL) is required to cause direct mechanical damage to the auditory system [93]. The level of inner ear cell injury and associated hearing loss is correlated with the intensity and duration of noise exposure $[4,102,103]$. Current data suggest that even sublethal injury of inner ear cells may accelerate the process of age-related hearing loss [102-104].

In addition, some animal studies have shown that noise exposure can cause injury at the synapse between the inner hair cells and auditory neurons that is not reflected on audiograms $[105,106]$. It has been suggested that this synaptic injury may be related to functional hearing loss and the degradation of speech intelligibility among other noise in the presence of normal audiometric thresholds $[106,107]$. The theory of synaptic injury has only been confirmed in animal models, and more evidence is needed to support this theory.

Except the direct damage on the auditory system, noise also can cause psychological and physiological disorders. Tinnitus, the subjective sensation of sound, is an effect of noise exposure that can be even more bothersome for individuals than hearing loss. Tinnitus often serves as an early sign of auditory injury [108]. The severity of tinnitus may be associated with the degree of NIHL. Tinnitus has several etiologies other than noise exposure. However, once hearing loss is noted, the cause of hearing loss is recognized as the cause of tinnitus, unless more evidence proves otherwise [107].

\section{Prevention measures}

At present, ONIHL is an irreversible disease with no effective treatment [18]. Prevention remains the best option for limiting the deteriorations of hearing power. A safe and healthy work environment is a basic requirement for all workers. The principal purpose of prevention 
measures for ONIHL includes monitoring occupational noise exposures (e.g., periodic noise exposure monitoring), reducing noise exposure in workplaces (e.g., engineering controls, administrative controls, and personal hearing protection), and early detection before permanent damage to the inner ear (e.g., routine audiometric examinations and health education) $[18,108,109]$.

For industrial noise, elimination or reduction of noise through engineering or administrative control is the best way of ONIHL intervention $[4,26]$. The risk of ONIHL can be minimized if noise is decreased to below $80 \mathrm{dBA}$ (weighted decibel relative to human ear) [21, 22]. For protection from hearing loss among workers, many nations have implemented legal standards regarding occupational noise exposure, and the majority ( $>80 \%$ ) of nations use a PEL of $85 \mathrm{dBA}$ and a 3-dB exchange rate in workplaces $[24,106]$. Engineering or scheduling changes is a very effective way to reduce the sources of noise in the workplace [110]. However, elimination of ONIHL is a large and long-term challenge at the individual, organizational policy, and population levels. The control measures for ONIHL need evidence-based evaluations that can provide policymakers with contextual evidence to implement ONIHL prevention and control programs.

Although decreasing noise production and personal exposure to noise through engineering and administrative controls may provide the most effective measures for reducing noise exposure of workers, these strategies are often difficult to achieve [103, 104]. When we cannot reduce the on-the-job environmental noise levels to acceptable standards, providing appropriate personal hearing protective devices (HPDs) and instructing workers to use protective devices become important alternative protective strategies $[24,110,111]$.

Hearing protection is a secondary level of protection measure. Both earmuffs and earplugs are commonly used as personal HPDs among workers. Previous studies suggest that using personal HPDs is effective in the prevention of ONIHL $[24,100]$. Data have shown that earplugs may not provide the advertised level of protection if employees are not instructed on their proper use [5]. Infrequent use of HPD and low perception of sound during HPD use are the most important factors influencing the effect of personal HPD usage in preventing ONIHL [112-116]. Continuous education of workers on the consistent use of HPD in noisy workplaces and implement of different interventional strategies are needed for promoting the use of HPD in the future.

\section{Conclusions}

In summary, ONIHL is still the most prevalent occupational disease in the world. The findings from this review provide guidance to policymakers in terms of where resources might best be used and can provide insight into the effectiveness of other past interventions. Treatment strategies are still in the developmental stages; before they become universally available, the main strategy for reducing the prevalence of ONIHL is prevention.

\section{Abbreviations}

AFFH: Agriculture, forestry, fishing, hunting; DALY: Disability-adjusted life year; HCA: Hearing Conservation Amendment; HLPP: Hearing loss prevention program; HPDs: Hearing protective devices; IHCs: Inner hair cells; MT: Mechanotransducer; NIOSH: National Institute for Occupational Safety and Health; NIHL: Noise-induced hearing loss; ONIHL: Occupational noiseinduced hearing loss; OSHA: Occupational Safety and Health Administration; OGE: Oil and gas extraction; OHCs: Outer hair cells; PEL: Permissible exposure limit; REL: Recommended exposure limit; SPL: Sound pressure level;

TTS: Temporary threshold shift; TWA: Time-weighted average

\section{Acknowledgements \\ None.}

\section{Authors' contributions}

Chen $\mathrm{KH}$, Su SB, and Chen KT contributed to the conception of the study. Chen $\mathrm{KH}$, Su SB, and Chen KT conducted the literature search and interpreted the results. Chen $\mathrm{KH}$ and Chen $\mathrm{KT}$ prepared the draft. Chen KT, the supervisor of the study, provided guidance on the review of literature and the direction of the study, and edited the final manuscript. All authors approved the final version of the manuscript.

\section{Funding}

This study was supported by a grant (No. 18YG19) from Sanming University Introduces High-Level Talent Research Start-Up Funds, Fujian Province, China.

\section{Availability of data and materials}

Data sharing is not applicable to this article as no dataset was generated or analyzed during the current study.

\section{Ethics approval and consent to participate}

Not applicable.

\section{Consent for publication}

Not applicable.

\section{Competing interests}

The authors declare that they have no competing interests.

\section{Author details}

${ }^{1}$ School of Mechanical and Electronic Engineering, Sanming University, Sanming 365, Fujian Province, China. ²Department of Occupational Medicine, Chi-Mei Medical Center, Tainan 710, Taiwan. ${ }^{3}$ Department of Occupational Medicine, Tainan Municipal Hospital (managed by Show Chwan Medical Care Corporation), No. 670, Chongde Road, East District, Tainan 701, Taiwan. ${ }^{4}$ Department of Public Health, College of Medicine, National Cheng Kung University, Tainan 701, Taiwan.

Received: 26 August 2020 Accepted: 25 October 2020

Published online: 31 October 2020

\section{References}

1. Nelson DI, Nelson RY, Concha-Barrientos M, Fingerhut M. The global burden of occupational noise-induced hearing loss. Am. J. Ind. Med. 2005;48:446-58.

2. Śliwińska-Kowalska M, Zaborowski K. WHO environmental noise guidelines for the European region: a systematic review on environmental noise and permanent hearing loss and tinnitus. Int. J. Environ. Res. Public Health. 2017; 14(10):1139.

3. Vos T, Flaxman AD, Naghavi M, Lozano R, Michaud C, Ezzati M, et al. Years lived with disability (YLDs) for 1160 sequelae of 289 diseases and injuries 1990-2010: a systematic analysis for the Global Burden of Disease Study 2010. Lancet. 2012;380:2163-96.

4. Hong O, Kerr MJ, Poling GL, Dhar S. Understanding and preventing noiseinduced hearing loss. Dis. Mon. 2013;59(4):110-8. 
5. Kerr MJ, Neitzel R, Hong O, Sataloff R. Historical review of efforts to reduce noiseinduced hearing loss in the United States. Am. J. Ind. Med. 2017;60:569-77.

6. Basner M, Babisch W, Davis A, Brink M, Clark C, Janssen S, et al. Auditory and non-auditory effects of noise on health. Lancet. 2014;383:1325-32.

7. Masterson EA, Tak S, Themann CL, Wall DK, Groenewold MR, Deddens JA, et al. Prevalence of hearing loss in the United States by industry. Am. J. Ind. Med. 2013;56:670-81.

8. Tak S, Davis RR, Calvert GM. Exposure to hazardous workplace noise and use of hearing protection devices among U.S. workers-NHANES, 1999-2004. Am. J. Ind. Med. 2009;52:358-71.

9. Masterson EA, Bushnel PT, Themann CL, Morata TC. Hearing impairment among noise-exposed workers — United States, 2003-2012 MMWR Morb. Mortal. Wkly. Rep. 2016;65:389-94.

10. Lin FR. Hearing loss in older adults: who's listening? JAMA. 2012;307:1147-8.

11. Seixas NS, Neitzel R, Stover B, Sheppard L, Daniell B, Edelson J, et al. A multicomponent intervention to promote hearing protector use among construction workers. Int. J. Audiol. 2011;50(Suppl 1):S46-56.

12. Amjad-Sardrudi H, Dormohammadi A, Golmohammadi R, Poorolajal J. Effect of noise exposure on occupational injuries: a cross-sectional study. J. Res. Health Sci. 2012;12:101-4.

13. Hoogendoorn WE, van Poppel MNM, Bongers PM, Koes BW, Bouter LM. Physical load during work and leisure time as risk factors for back pain. Scand. J. Work Environ. Health. 1999:25(5):387-403.

14. Mirza R, Kirchner B, Dobie RA, Crawford J. Occupational noise-induced hearing loss. J. Occup. Environ. Med. 2018;60:e498-501.

15. Wada T, Sano H, Nishio SY, Kitoh R, Ikezono T, Iwasaki S, et al. Differences between acoustic trauma and other types of acute noise-induced hearing loss in terms of treatment and hearing prognosis. Acta. Otolaryngol. 2017; 137(sup565):S48-52.

16. Le TN, Straatman LV, Lea J, Westerberg B. Current insights in noise-induced hearing loss: a literature review of the underlying mechanism, pathophysiology, asymmetry, and management options. J. Otolaryngol. Head Neck Surg. 2017;46(1):41.

17. Lie A, Engdahl B, Hoffman HJ, Li CM, Tambs K. Occupational noise exposure, hearing loss, and notched audiograms in the HUNT Nord-Trøndelag hearing loss study, 1996-1998. Laryngoscope. 2017;127(6):1442-50.

18. Kirchner DB, Evenson E, Dobie RA, Rabinowitz P, Crawford J, Kopke R, Hudson TW. Occupational noise-induced hearing loss: ACOEM Task Force on Occupational Hearing Loss. J. Occup. Environ. Med. 2012;54(1):106-8.

19. Nelson DI, Concha-Barrientos M, Driscoll T, Steenland K, Fingerhut M, Punnett $L$, et al. The global burden of selected occupational diseases and injury risks: methodology and summary. Am. J. Ind. Med. 2005;48(6):400-18.

20. Pelegrin AC, Canuet L, Rodríguez ÁA, Morales MP. Predictive factors of occupational noise-induced hearing loss in Spanish workers: a prospective study. Noise Health. 2015;17(78):343-9.

21. Occupational Safety and Health Administration (OSHA). Technical manualsection II, chapter 5, noise measurement. OSHA, Washington, DC, http:// www.osha-slc.gov/TechMan_data/TM28.html.

22. National Institute for Occupational Safety and Health (NIOSH). Criteria for a recommended standard: occupational exposure to noise. 1972 (Publication No. 73-11001).

23. National Institute for Occupational Safety and Health (NIOSH). Criteria for a recommended standard: occupational exposure to noise. Revised Criteria. http://www.cdc.gov/98-126.html.

24. Sriwattanatamma P, Breysse P. Comparison of NIOSH noise criteria and OSHA hearing conservation criteria. Am. J. Ind. Med. 2000;37:334-8.

25. ISO. Determination of occupational noise exposure and estimation of noiseinduced hearing impairment, 2nd ed. International Standard Organization, Geneva, Switzerland, ISO No. 1999, 1990 (E).

26. Johnson DL. The development of the data base for ISO-1999, an evaluation of strength and weakness. J. Acoust. Soc. Am. 1994;95(5):2861.

27. Passchier-Vermeer W. Hearing loss due to continuous exposure to steadystate broad band noise. J. Acoust. Soc. Am. 1974;56(5):1585-93.

28. Prince MM, Stayner LT, Smith RJ, Gilbert SJ. A re-examination of risk estimates from the NIOSH occupational noise and hearing survey (ONHS). J. Acoust. Soc. Am. 1997;101:950-63.

29. Goley GS, Song WJ, Kim JH. Kurtosis corrected sound pressure level as a noise metric for risk assessment of occupational noise. Accoust. Soc. Am. 2011;129(3):1475-8.

30. Niwa K, Mizutari K, Matsui T, Kurioka T, Matsunobu T, Kawauchi S, et al. Pathophysiology of the inner ear after blast injury caused by laser-induced shock wave. Sci. Rep. 2016;6:31754.
31. Lesage FX, Jovenin N, Deschamps F, Vincent S. Noise-induced hearing loss in French police officers. Occup. Med. (Lond). 2009;59(7):483-6.

32. Engdahl B, Tambs K. Occupation and the risk of hearing impairment--results from the Nord-Trøndelag study on hearing loss. Scand. J. Work Environ. Health. 2010;36(3):250-7.

33. Leensen MC, van Duivenbooden JC, Dreschler WA. A retrospective analysis of noise-induced hearing loss in the Dutch construction industry. Int. Arch. Occup. Environ. Health. 2011;84(5):577-90.

34. Kitcher ED, Ocansey G, Tumpi DA. Early occupational hearing loss of workers in a stone crushing industry: our experience in a developing country. Noise Health. 2012;14:68-71.

35. Strauss S, Swanepoel DW, Becker P, Eloff Z, Hall JW 3rd. Prevalence and degree of noise-induced hearing loss in South African gold miners. J. Occup Health South Afr. 2012;18:20-5.

36. Chadambuka A, Mususa F, Muteti S. Prevalence of noise induced hearing loss among employees at a mining industry in Zimbabwe. Afr. Health Sci. 2013;13(4):899-906.

37. Kitcher ED, Ocansey G, Abaidoo B, Atule A. Occupational hearing loss of market mill workers in the city of Accra, Ghana. Noise Health. 2014;16(70): $183-8$.

38. Robinson T, Whittaker J, Acharya A, Singh D, Smith M. Prevalence of noiseinduced hearing loss among woodworkers in Nepal: a pilot study. Int. J. Occup. Environ. Health. 2015;21(1):14-22.

39. Lawson SM, Masterson EA, Azman AS. Prevalence of hearing loss among noise-exposed workers within the mining and oil and gas extraction sectors, 2006-2015. Am. J. Ind. Med. 2016;62(10):826-37.

40. Masterson EA, Themann CL, Calvert GM. Prevalence of hearing loss among noise-exposed workers within the agriculture, forestry, fishing, and hunting sector, 2003-2012. Am. J. Ind. Med. 2018;61(1):42-50.

41. Dement J, Welch LS, Ringen K, Cranford K, Quinn P. Hearing loss among older construction workers: updated analyses. Am. J. Ind. Med. 2018;61:326-35.

42. Thepaksorn P, Koizumi A, Harada K, Siriwong W, Neitzel RL. Occupational noise exposure and hearing defects among sawmill workers in the South of Thailand. Int. J. Occup. Saf. Ergon. 2019;25(3):458-66.

43. Chen Y, Zhang M, Qiu W, Sun X, Wang X, Dong Y, et al. Prevalence and determinants of noise-induced hearing loss among workers in the automotive industry in China: a pilot study. J. Occup. Health. 2019;61(5): 387-97.

44. Almaayeh M, Al-Musa A, Khader YS. Prevalence of noise induced hearing loss among Jordanian industrial workers and its associated factors. Work. 2018;61:267-71.

45. Kim SH, Cha ES, Cha HE, Song JJ, Chae SW. Prevalence and clinical aspects of hearing loss among the South Korean adolescent: data from a population-based study. Int. J. Pediatr. Otorhinolaryngol. 2020;128:109698.

46. van der Molen HF, Marsili C, Vitali A, Colosio C. Trends in occupational diseases in the Italian Agricultural Sector, 2004-2017. Occup. Environ. Med. 2020;77(5):340-3.

47. Oksa P, Sauni R, Talola N, Virtanen S, Nevalainen J, Saalo A, et al. Trends in occupational diseases in Finland, 1975-2013, A Register Study. BMJ Open. 2019;9(4):e024040

48. van der Molen HF, de Vries SC, Stocks SJ, Warning J, Frings-Dresen MH. Incidence rates of occupational diseases in the Dutch construction sector, 2010-2014. Occup. Environ. Med. 2016;73(5):350-2.

49. Sriopas A, Chapman RS, Sutammasa S, Siriwong W. Occupational noiseinduced hearing loss in auto part factory workers in welding units in Thailand. J. Occup. Health. 2017;59(1):55-62.

50. Swan AA, Nelson JT, Swiger B, Jaramillo CA, Eapen BC, Packer M, et al. Prevalence of hearing loss and tinnitus in Iraq and Afghanistan veterans: a chronic effects of neurotrauma consortium study. Hear Res. 2017;349:4-12.

51. Musiba Z. The prevalence of noise-induced hearing loss among Tanzanian miners. Occup. Med. (Lond). 2015;65(5):386-90.

52. Feder K, Michaud D, McNamee J, Fitzpatrick E, Davies H, Leroux T, et al. Prevalence of hazardous occupational noise exposure, hearing loss, and hearing protection usage among a representative sample of working Canadians. J. Occup. Environ. Med. 2017;59(1):92-113.

53. Mizoue T, Miyamoto T, Shimizu T. Combined effect of smoking and occupational exposure to noise on hearing loss in steel factory workers. Occup. Environ. Med. 2003;60(1):56-9.

54. Kerns E, Masterson EA, Themann CL, Calvert GM. Cardiovascular conditions, hearing difficulty, and occupational noise expose within U.S. industries and occupations. Am J. Ind. Med. 2018;61(6):477-91. 
55. Tsukada T, Sakakibara H. A trail of individual education for hearing protection with an instrument that measures the noise attenuation effect of wearing earplugs. Ind. Health. 2008;46(4):393-6.

56. Stocks SJ, McNamee R, van der Molen HF, Paris C, Urban P, Campo G, et al. Trends in incidence of occupational asthma, contact dermatitis, noiseinduced hearing loss, carpal tunnel syndrome and upper limb musculoskeletal disorders in European countries from 2000 to 2012. Occup. Environ. Med. 2015;72(4):294-303.

57. Masterson EA, Themann CL, Calvert GM. Prevalence of hearing loss among noise-exposed workers within the Health Care and Social Assistance Sector, 2003-2012. J. Occup. Environ. Med. 2018;60(4):350-6.

58. Masterson EA, Bushnell PT, Themann CL, Morata TC. Hearing impairment among noise-exposed workers — United States, 2003-2012. MMWR Morb. Mortal. Wkly. Rep. 2016;65(15):389-94.

59. Marlenga B, Berg RL, Linneman JG, Wood DJ, Kirkhorn SR, Pickett W, et al. Determinants of early-stage hearing loss among a cohort of young workers with 16-year follow-up. Occup. Environ. Med. 2012;69(7):479-84.

60. Hong $\mathrm{O}$. Hearing loss among operating engineers in American construction industry. Int. Arch. Occup. Environ. Health. 2005;78:565-74.

61. Hessel PA. Hearing loss among construction workers in Edmonton, Alberta, Canada. J. Occup. Environ. Med. 2000;42:57-63.

62. Palmer KT, Griffin MJ, Syddall HE, Davis A, Pannett B, Coggon D. Occupational exposure to noise and the attributable burden of hearing difficulties in Great Britain. Occup. Environ. Med. 2002;59(9):634-9.

63. OlogeFE ATM, Olajide TG. Occupational noise exposure and sensorineural hearing loss among workers of a steel rolling mill. Eur. Arch. Otorhinolaryngol. 2006;263(7):618-21.

64. Pouryaghoub G, Mehrdad R, Pourhosein S. Noise-induced hearing loss among professional musicians. J. Occup. Health. 2017:59(1):33-7.

65. Chen JD, Tsai JY. Hearing loss among workers at an oil refinery in Taiwan. Arch. Environ. Health. 2003;58(1):55-8.

66. Shuste BZ, Depireux DA, Mong JA, Hertzano R. Sex differences in hearing: probing the role of estrogen signaling. J. Acoust. Soc. Am. 2019;145(6): 3656-63.

67. Grobler LM, Swanepoel W, Strauss S, Becker P, Eloff Z. Occupational noise and age: a longitudinal study of hearing sensitivity as a function of noise exposure and age in South African gold mine workers. S. Afr. J. Commun. Disord. 2020;67(2):e1-7.

68. Girard SA, Leroux T, Courteau M, Picard M, Turcotte F, Richer O. Occupational noise exposure and noise-induced hearing loss are associated with workrelated injuries leading to admission to hospital. Inj. Prev. 2015;21:e88-92.

69. van Kempen EE, Kruize H, Boshuizen HC, Ameling CB, Staatsen BA, de Hollander AE. The association between noise exposure and blood pressure and ischemic heart disease: a meta-analysis. Environ. Health Perspect. 2002; 110:307-17.

70. Tomei G, Fioravanti M, Cerratti D, Sancini A, Tomao E, Rosati MV, et al. Occupational exposure to noise and the cardiovascular system: a metaanalysis. Sci. Total Environ. 2010;408:681-9.

71. Davies H, Kamp IV. Noise and cardiovascular disease: a review of the literature 2008-2011. Noise Health. 2012;14:287-91.

72. Huss A, Spoerri A, Egger M, Röösli M. Swiss National Cohort Study Group. Aircraft noise, air pollution, and mortality from myocardial infarction. Epidemiology. 2010:21:829-36.

73. Sørensen M, Hvidberg M, Andersen ZJ, Nordsborg RB, Lillelund KG, Jakobsen J, et al. Road traffic noise and stroke: a prospective cohort study. Eur. Heart J. 2011;32:737-44.

74. Gan WQ, Davies HW, Koehoorn M, Brauer M. Association of long-term exposure to community noise and traffic-related air pollution with coronary heart disease mortality. Am. J. Epidemiol. 2012;175:898-906.

75. Karpa MJ, Gopinath B, Beath K, Rochtchina E, Cumming RG, Wang JJ, et al. Associations between hearing impairment and mortality risk in older persons: the Blue Mountains Hearing Study. Ann. Epidemiol. 2010;20:452-9.

76. Lusk SL, Gillespie B, Hagerty BM, Ziemba RA. Acute effects of noise on blood pressure and heart rate. Arch. Environ. Health. 2004;59:392-9.

77. Sayler SK, Rabinowitz PM, Cantley LF, Galusha D, Neitzel RL. Costs and effectiveness of hearing conservation programs at 14 US metal manufacturing facilities. Int. J. Audiol. 2018;57:S3-S11.

78. Fettiplace R. Hair cell transduction, tuning and synaptic transmission in the mammalian cochlea. Compr. Physiol. 2017;7(4):1197-227.

79. Lim D. Functional structure of the organ of Corti: a review. Hear Res. 1986; 22:117-46.
80. Fettiplace R, Kim K. The physiology of mechanoelectical transduction channels in hearing. Physiol. Rev. 2014;94(3):951-86.

81. Kujawa SG, Liberman MC. Acceleration of age-related hearing loss by early noise exposure: evidence of a misspent youth. J. Neurosci. 2006;26(7):2115-23.

82. Shi L, Liu K, Wang H, Zhang $Y$, Hong Z, Wang M, et al. Noise induced reversible changes of cochlear ribbon synapses contribute to temporary hearing loss in mice. Acta. Otolaryngol. 2015;135(11):1093-102.

83. Henderson D, Bielefeld EC, Harris KC. The role of oxidative stress in noiseinduced hearing loss. Ear Hear. 2006;27(1):1-19.

84. Kurabi A, Keithley EM, Housley GD, Ryan AF, Wong AC. Cellular mechanisms of noise-induced hearing loss. Hear Res. 2017;349:129-37.

85. Le Prell CG. Effects of noise exposure on auditory brainstem response and speech-in-noise tasks: a review of the literature. Int. J. Audiol. 2019;58:S3-S32.

86. Baradarnfar MH, Karamifar K, Mehrparvar AH, Mollasadeghi A, Gharavi M, Karimi G, et al. Amplitude changes in otoacoustic emissions after exposure to industrial noise. Noise Health. 2012;14(56):28-31.

87. Alvarado JC, Fuentes-Santamarı V, Melgar-Rojas P, Valero ML, Gabaldon-UII MC, Miller JM, et al. Synergistic effects of free radical scavengers and cochlear vasodilators: a new otoprotective strategy for age-related hearing loss. Front. Aging Neurosci. 2015;7:86

88. Sayler SK, Roberts BJ, Manning MA, Sun K, Neitzel RL. Patterns and trends in OSHA occupational noise exposure measurements from 1979 to 2013. Occup. Environ. Med. 2019;76(2):118-24.

89. Kujawa SG, Liberman MC. Adding insult to injury: cochlear nerve degeneration after "temporary" noise-induced hearing loss. J. Neurosci. 2009;29(45):14077-85.

90. Le Prell CG, Dolan DF, Bennett DC, Boxer PA. Nutrient plasma levels achieved during treatment that reduces noise-induced hearing loss. Transl. Res. 2011;158:54-70.

91. Themann $\mathrm{CL}$, Suter $\mathrm{AH}$, Stephenson MR. National research agenda for the prevention of occupational hearing loss_-part 1. Sem. Hear. 2013;34(3):145-207.

92. Nordmann AS, Bohne BA, Harding GW. Histopathological differences between temporary and permanent threshold shift. Hear. Res. 2000;115:93-100.

93. Hill K, Yuan $\mathrm{H}$, Wang $X$, Sha SH. Noise-induced loss of hair cells and cochlear synaptopathy are mediated by the activation of AMPK. J. Neurosci. 2016; 36(28):7497-510.

94. Themann $\mathrm{CL}$, Suter $\mathrm{AH}$, Stephenson MR. National research agenda for the prevention of occupational hearing loss_-part 2. Sem. Hear. 2013;34(3):208-51.

95. Abaamrane L, Raffin F, Gal M, Avan P, Sendowski I. Long-term administration of magnesium after acoustic trauma caused by gunshot noise in guinea pigs. Hear Res. 2009;247:137-45.

96. Kopke RD, Jackson RL, Coleman JK, Liu J, Bielefeld EC, Balough BJ. NAC for noise: from the bench top to the clinic. Hear Res. 2007;226:114-25.

97. Kramer S, Dreisbach L, Lockwood J, Baldwin K, Kopke R, Scranton S, O'Leary $\mathrm{M}$. Efficacy of the antioxidant $\mathrm{N}$-acetylcysteine (NAC) in protecting ears exposed to loud music. J. Am. Acad. Audiol. 2006;17(4):265-78.

98. Lin CY, Wu JL, Shih TS, Tsai PJ, Sun YM, Ma MC, Guo YL. N-Acetyl-cysteine against noise-induced temporary threshold shift in male workers. Hear Res. 2010;269:42-7.

99. Chen GD, Daszynski DM, Ding D, Jiang H, Woolman T, Blessing K, et al. Novel oral multifunctional antioxidant prevents noise-induced hearing loss and hair cell loss. Hear Res. 2020;388:107880.

100. Fernandez KA, Guo D, Micucci S, De Gruttola V, Liberman MC, Kujawa SG. Noise-induced cochlear synaptopathy with and without sensory cell loss. Neuroscience. 2020:427:43-57.

101. Samson J, Wiktorek-Smagur A, Politanski P, Rajkowska E, PawlaczykLuszczynska M, Dudarewicz A, et al. Noise-induced time-dependent changes in oxidative stress in the mouse cochlea and attenuation by $D$ methionine. Neuroscience. 2008;152:146-50.

102. Niemann H, Bonnefoy X, Braubach M, Hecht K, Maschke C, Rodrigues C, Röbbel N. Noise-induced annoyance and morbidity results from the panEuropean LARES study. Noise Health. 2006;8(31):63-79.

103. Gates GA, Schmid P, Kujawa SG, Nam B, D'Agostino R. Longitudinal threshold changes in older men with audiometric notches. Hear Res. 2000;141:220-8.

104. Campo P, Venet T, Rumeau C, Thomas A, Rieger B, Cour C, et al. Impact of noise or styrene exposure on the kinetics of presbycusis. Hear Res. 2011;280:122-32.

105. Liberman MC, Kujawa SG. Cochlear synaptopathy in acquired sensorineural hearing loss: manifestations and mechanisms. Hear Res. 2017;349:138-47.

106. Tuerdi A, Kinoshita M, Kamogashira T, Fujimoto C, Iwasaki S, Shimizu T, Yamasoba T. Manganese superoxide dismutase influences the extent of noise-induced hearing loss in mice. Neurosci. Lett. 2017;642:123-8. 
107. Kobel M, Le Prell CG, Liu J, Hawks JW, Bao J. Noise-induced cochlear synaptopathy: past findings and future studies. Hear Res. 2017;349:148-54.

108. Money A, Carder M, Turner S, Hussey L, Agius R. Surveillance for workrelated audiological disease in the UK: 1998-2006. Occup. Med. (Lond.). 2011;61(4):226-33.

109. Leensen MC, Dreschler WA. Longitudinal changes in hearing threshold levels of noise-exposed construction workers. Int. Arch. Occup. Environ. Health. 2015;88:45-60.

110. Rabinowitz PM, Galusha D, Kirsche SR, Cullen MR, Slade MD, Dixon-Ernst C. Effect of daily noise exposure monitoring on annual rates of hearing loss in industrial workers. Occup. Environ. Med. 2011;68(6):414-8.

111. Brink LL, Talbott EO, Burks JA, Palmer CV. Changes over time in audiometric thresholds in a group of automobile stamping and assembly workers with a hearing conservation program. AlHA J (Fairfax, Va). 2002;63:482-7.

112. Saleh S, Woskie S, Bello A. The use of noise dampening mats to reduce heavy-equipment noise exposures in construction. Saf. Health Work. 2017;8: 226-30.

113. Hong O, Ronis DL, Lusk SL, Kee GS. Efficacy of a computer-based hearing test and tailored hearing protection intervention. Int. J. Behav. Med. 2006; 13(4):304-14.

114. Kerr MJ, Savik K, Monsen KA, Lusk SL. Effectiveness of computer-based tailoring versus targeting to promote use of hearing protection. Can. J. Nurs. Res. 2007;39:80-97.

115. McCullagh M, Lusk SL, Ronis DL. Factors influencing use of hearing protection among farmers: a test of the Pender Health Promotion model. Nurs. Res. 2002;51:33-9.

116. Hong O, Chin DL, Ronis DL. Predictors of hearing protection behavior among firefighters in the United States. Int. J. Behav. Med. 2013;20:121-30.

\section{Publisher's Note}

Springer Nature remains neutral with regard to jurisdictional claims in published maps and institutional affiliations.

Ready to submit your research? Choose BMC and benefit from:

- fast, convenient online submission

- thorough peer review by experienced researchers in your field

- rapid publication on acceptance

- support for research data, including large and complex data types

- gold Open Access which fosters wider collaboration and increased citations

- maximum visibility for your research: over $100 \mathrm{M}$ website views per year

At $\mathrm{BMC}$, research is always in progress.

Learn more biomedcentral.com/submissions 